\title{
PENGARUH EKSTRAK ETANOL PROPOLIS TERHADAP EKSPRESI PROTEIN BCL2 DAN P21 DALAM MENEKAN PROLIFERASI DAN MENGINDUKSI APOPTOSIS PADA KULTUR SEL HEPATOMA (Hep G2)
}

\author{
THE EFFECT OF ETHANOL PROPOLIS EXTRACT ON BCL2 AND P21 PROTEIN \\ EXPRESSION ON PROLIFERATION SUPRESION AND INDUCING APOPTOSIS IN \\ HEPATOMA CELLS CULTURE (HeP G2)
}

\author{
Kun Salimah, Paulus Kusnanto, Bambang Purwanto \\ Program PPDS I Ilmu Penyakit Dalam. Universitas Sebelas Maret Surakarta. \\ Korespondensi: dr. Kun Salimah, Sp. PD. Email: kun.perdana@gmail.com
}

\begin{abstract}
ABSTRAK
Karsinoma Hepatoseluler (KHS) merupakan 90\% dari tumor primer di hati. Salah satu pengobatan alami yang diketahui memiliki aktivitas anti kanker adalah propolis. Aktivitas anti kankernya bekerja melalui induksi apoptosis dan penghambatan proliferasi sel. Bcl2 termasuk kelompok famili protein B-cell lymphoma 2 yang berperan sebagai protein apoptosis jalur intrinsic. p21 merupakan suatu protein tumor suppresor yang memiliki fungsi utama dalam menghambat progresi siklus sel. Penelitian ini bertujuan untuk mengetahui efek anti kanker ekstrak etanol propolis (EEP) yang berasal dari Kerjo, Karanganyar pada kultur sel kanker hepatoseluler (Hep G2) melalui potensinya sebagai antikanker dalam meningkatkan ekspresi protein p21, menurunkan ekspresi protein bcl2 dalam menekan apoptosis dan menurunkan proliferasi sel. Penelitian ini merupakan penelitian experimental laboratories dengan post test with control group design. Dilakukan pada sel Hep G2 dengan perlakuan pemberian konsentrasi EEP (1/2IC50, IC50, 2IC50), sorafenib IC50, kombinasi EEP IC50+ sorafenib IC50, dan kontrol. Pengamatan ekspresi protein Bcl2 dan p21 dengan metode imunositokimia, pengamatan proliferasi sel dengan doubling time, pengamatan apoptosis dengan flowcytometry. Uji statistik menggunakan ANOVA, dilanjutkan dengan uji post hoc Tuckey, dinyatakan bermakna bila p<0,05. Konsentrasi penghambatan $50 \%$ sel Hep G2 oleh EEP 65,2 $\mu \mathrm{g} / \mathrm{mL}$, dan sorafenib $(6,08 \mu \mathrm{g} / \mathrm{mL})$. EEP konsentrasi $2 I C 50(p=0,001)$, sorafenib 1 IC50 $(p=0,001)$, 1IC50 EEP+ 1IC50 sorafenib $(p=0,001)$ mampu meningkatkan ekspresi protein p21. Konsentrasi 2 EEP $(p=0,040)$, mampu menurunkan ekpresi protein Bcl2, dengan p=0,001. Kekuatan EEP 1IC50 setara dengan sorafenib IC50 dalam menekan proliferasi 24 jam ( $p>0,05)$. Kekuatan EEP 0,5IC50 setara dengan sorafenib IC50 dalam menekan proliferasi 48 jam (p>0,05). Kekuatan EEP 1 IC50 lebih baik dari sorafenib IC50 dalam menekan proliferasi 72 jam ( $p>0,05)$. Semua konsentrasi EEP meningkatkan ekspresi protein p21, dengan kelompok EEP 2IC50 memberikan efek paling kuat. Semua konsentrasi EEP mampu menurunkan proliferasi sel, dengan kelompok EEP 2IC50, memberikan efek paling kuat. Konsentrasi 2 IC50 EEP berpengaruh terhadap penurunan ekspresi protein bcl 2 dan apoptosis sel hepatoma.
\end{abstract}

Kata kunci: Ekstrak Etanol Propolis, Bcl2, P21, Apoptosis, Proliferasi, Sel Hep G2

\begin{abstract}
Hepatocellular carcinoma (KHS) is $90 \%$ of primary tumors in the liver. One of natural treatment that have anticancer activity is propolis. Its anti-cancer activity works through induction of apoptosis and inhibition of cell proliferation. Bcl2 belongs to the family group B-cell lymphoma 2 protein which acts as an intrinsic pathway apoptotic protein. p21 is a tumor suppressor protein that has a primary function in inhibiting cell cycle progression. This study was aimed to determine the anti-cancer effect of propolis ethanol extract (EEP) originating from Kerjo, Karanganyar on hepatocellular cancer cell culture (Hep G2) through its potential as an anticancer in increasing p21 protein expression, reducing bcl2 protein expression in suppressing apoptosis and reducing cell proliferation . This research is an experimental laboratories with post test with control group design. Performed on Hep G2 cells with the treatment of EEP concentrations (1/2IC50, IC50, 2IC50), sorafenib IC50, a combination of EEP IC50 + sorafenib IC50, and controls. Observation of Bcl2 and p21 protein expression by immunocytochemistry method, observing cell proliferation with doubling time, observing apoptosis with flowcytometry. We use ANOVA statistical test, followed by the Tuckey post hoc test, were stated to be significant if $p<0.05$. The inhibition concentration of $50 \%$ Hep G2 cells by EEP was $65.2 \mu \mathrm{g} / \mathrm{mL}$, and sorafenib $(6.08 \mu \mathrm{g} / \mathrm{mL})$. EEP concentration of $2 \mathrm{IC} 50(\mathrm{p}=0.001)$, sorafenib 1 IC50 $(p=0.001)$, IIC50 EEP $+1 I C 50$ sorafenib $(p=0.001)$ able to increase p21 protein expression. The 2 EEP concentration $(p=0.040)$, was able to reduce the expression of Bcl2 protein, with $p=0.001$. The strength
\end{abstract}


of EEP 1IC50 is equivalent to sorafenib IC50 in suppressing 24-hour proliferation ( $p>0.05$ ). The strength of EEP $1 / 2$ IC50 is equivalent to sorafenib IC50 in suppressing proliferation 48 hours $(p>0.05)$. The strength of EEP 1IC50 is better than sorafenib IC50 in suppressing proliferation of 72 hours ( $p>0.05)$. All EEP concentrations increase p21 protein expression, with the EEP 2IC50 group providing the strongest effect. All EEP concentrations were able to reduce cell proliferation, with the EEP $2 I C 50$ group, giving the strongest effect. It was concluded that concentration of 2IC50 EEP has an effect on decreasing the expression of bcl2 protein and hepatoma cell apoptosis.

Keywords: Ethanol Extract Propolis, Bcl2, P21, Apoptosis, Proliferation, Hep G2 Cells

How To Cite: Salimah, K., Kusnanto, P., \& Purwanto, B. (2019). PENGARUH EKSTRAK ETANOL PROPOLIS TERHADAP EKSPRESI PROTEIN BCL2 DAN P21 DALAM MENEKAN PROLIFERASI DAN MENGINDUKSI APOPTOSIS PADA KULTUR SEL HEPATOMA (Hep G2). Biomedia, 11(1), 5-10. doi:https://doi.org/10.23917/biomedika.v11i1.5364

DOI: https://doi.org/10.23917/biomedika.v11i1.5364

\section{PENDAHULUAN}

Kanker hati merupakan keganasan peringkat keenam di seluruh dunia dengan prognosis yang kurang baik. (Parkin, 2002). Menurut data dari Globocan 2012, kanker hati lebih banyak menyerang jenis kelamin laki-laki daripada perempuan dan rasio insidensi terjadinya kanker hati pada laki laki: perempuan adalah: 2,4: 1. Kebanyakan kanker hati merupakan kanker hati primer yaitu sekitar 70\%-85\% (Ahmed et al., 2008).

Propolis telah digunakan secara aman oleh dokter di Brazil, Jepang dan beberapa negara lain sebagai nutrisi suportif yang menyertai terapi standar untuk kanker (Paulino et al., 2009). Propolis terdiri dari campuran resin, serbuk sari dan lilin tanaman yang dikumpulkan lebah dari berbagai jenis tanaman dan digunakan untuk proteksi sarang lebah dari mikroba (Ananda, 2013; Watanabe, 2011). Propolis memodulasi target sel pada sel kanker yang berbeda seperti nuclear transcription factor $(N F \kappa B)$; jalur translasional pada Ras-GTPase $g$; jalur p38-MAPK, jalur $P I 3 K / A k t / P K B$; jalur $C O X-2$ dan prostaglandin $\mathrm{E}_{2}$; dan ekspresi $i N O S$ atau $e-N O S$ dan produksi nitrit oksida. Juga memodulasi fragmentasi DNA yang diinduksi jalur Cytochrome-C; protein p53; pelepasan protein proapoptosis BAx dan Bak; inhibisi neoangiogenesis dengan modulasi pada ekspresi matrix metalloproteinases (MMPs) dan vascular endothelial growth factor (VEGF), mengatur diferensisasi sel melalui protein $p 21$ (Wafl/Cip1) yang berhubungan dengan CDK2 dan cyclin E. Oleh karena itu propolis digunakan untuk meningkatkan efikasi obat kemoterapi (Paulino et al., 2009).
Aktivitas antikanker propolis ini dipengaruhi oleh geografis dan tumbuhan sebagai asal pengumpulan resin oleh lebah untuk membentuk propolis (Syamsudin, 2009). Berdasarkan fakta-fakta yang diuraikan di atas, mendorong peneliti untuk mengetahui pengaruh pemberian propolis yang berasal dari Kerjo, Karanganyar, Indonesia terhadap peningkatan ekspresi p21 dan induksi apoptosis, terutama terkait dengan peningkatan ekspresi protein, p21 dan penurunan Bcl2 pada kultur sel Hep G2 (cell line kanker hepar).

Penelitian tentang efek anti kanker ekstrak etanol propolis (EEP) yang berasal dari Kerjo, Karanganyar pada kultur sel kanker hepatoseluler (Hep G2) melalui potensinya sebagai antikanker dalam meningkatkan ekspresi protein p21, menurunkan ekspresi protein bcl2 dalam menekan apoptosis dan menurunkan proliferasi sel belum pernah dilakukan.

\section{METODE}

Rancangan penelitian ini yaitu penelitian experimental laboratories, post test with control group design. Penelitian dilakukan pada kultur sel kanker hepatoma Hep G2 dengan pemberian ekstrak etanol propolis konsentrasi EEP (1/2IC50, IC50, 2IC50), Sorafenib IC50, kombinasi EEP IC50 + Sorafenib IC50, dan kontrol. Pengamatan ekspresi Bcl2 dan p21 dilakukan dengan metode imunositokimia, pengamatan proliferasi dengan metode doubling time, apoptosis dengan flowcytometry. Analisis statistik menggunakan IBM SPSS 20. Uji statistik menggunakan ANOVA. Jika data distribusi normal dilanjutkan dengan LSD post hoc test. Sedangkan jika data 
distribusi tidak normal dilanjutkan dengan uji Kruskal-Wallis yang akan dilanjutkan dengan Mann whitney. Dinyatakan bermakna bila $\mathrm{p}<0,05$.

\section{HASIL DAN PEMBAHASAN}

1. Uji sitotoksisitas dengan MTTassay untuk menetapkan nilai IC50 ekstrak etanol propolis dan Sorafenib.

Sel Hep G2 ditumbuhkan pada media komplit, selanjutnya diberikan perlakuan dengan ekstrak etanol propolis. Sel Hep G2 yang hidup memiliki morfologi berbentuk poligonal dan menempel pada dasar sumuran, sedangkan sel Hep G2 yang mati bentuknya menjadi bulat dan lebih kecil dari sel hidup, tersebar dan tidak menempel pada dasar sumuran. Data yang didapat dari uji sitotoksisitas dengan MTT assay berupa absorbansi dari tiap sumuran yang merupakan hasil pembacaan dengan menggunakan ELISA reader pada panjang gelombang $595 \mathrm{~nm}$. Untuk mendapatkan persentase viabilitas sel, data yang didapat tersebut kemudian diolah lebih lanjut dengan perhitungan cara yaitu membandingkan nilai absorbansi antara sel yang diberi perlakuan dan kontrol (sel tanpa perlakuan) setelah masingmasing dikurangi dengan kontrol media (blank). Data tersebut digunakan untuk menetapkan nilai IC50 bahan uji dengan menggunakan analisis regresi linear antara dosis bahan uji dan persentase viabilitas sel Hep G2. Nilai rata-rata persentase viabilitas sel Hep G2 dan IC50 dari bahan uji ditunjukkan pada Tabel 1

Tabel 1. Nilai Rata-rata Presentase Viabilitas sel Hep

\begin{tabular}{cccc}
\multicolumn{4}{c}{ G2 dan IC50 } \\
\hline Bahan Uji & $\begin{array}{c}\text { Konsentrasi } \\
(\boldsymbol{\mu g} / \mathbf{~ m L})\end{array}$ & $\begin{array}{c}\text { Rata-rata Viabilitas } \\
\text { sel Hep G2 }(\boldsymbol{\%} \pm \mathbf{S D})\end{array}$ & $\begin{array}{c}\mathbf{I C}_{\mathbf{5 0}} \pm \mathbf{S D} \\
(\boldsymbol{\mu g} \mathbf{~ m L})\end{array}$ \\
\hline \multirow{2}{*}{ Ekstrak } & 7,8 & $106,33 \pm 0,89$ & \\
Etanol & 15,6 & $112,59 \pm 1,19$ & \\
Propolis & 62,5 & $67,84 \pm 1,79$ & $65,19 \pm 1,81$ \\
(EEP) & 125 & $12,83 \pm 2,09$ & \\
& 250 & $4,49 \pm 2,39$ & \\
& 6,2 & $101,87 \pm 0,79$ & \\
Sorafenib & 12,5 & $84,91 \pm 1,09$ & \\
& 25 & $59,84 \pm 1,39$ & $6,08 \pm 0,78$ \\
& 50 & $45,18 \pm 1,69$ & \\
\hline
\end{tabular}

Tabel 1. menunjukkan bahwa secara umum peningkatan konsentrasi EEP mengakibatkan penurunan persentase viabilitas sel Hep G2. Pada konsentrasi EEP yang tertinggi $(250 \mu \mathrm{g} / \mathrm{mL})$, diperoleh persentase viabilitas sel Hep G2 yang terendah (4,49\%). Pada pemberian Sorafenib secara umum lebih efektif dengan pemberian EEP, karena pada konsentrasi yang tertinggi $(100 \mu \mathrm{g} / \mathrm{uL})$ persentase viabilitas sel Hep G2 (mencapai 37\%). Dari analisis regresi linear diperoleh nilai IC50 EEP sebesar $65,9 \mu \mathrm{g} / \mathrm{mL}$. kemudian nilai IC50 EEP yang didapat ini digunakan sebagai dasar penentuan konsentrasi EEP pada uji selanjutnya, yaitu sebesar 60, 121, dan $242 \mu \mathrm{g} / \mathrm{mL}$ (1/2 IC50, IC50, dan 2 IC50). Nilai IC50 sorafenib yaitu sebesar $6,08 \mu \mathrm{g} / \mathrm{mL}$ akan digunakan sebagai kontrol positif.

2. Pengamatan ekspresi protein $\mathrm{P} 21$

p21 adalah suatu tumor suppresor protein memiliki fungsi utama dalam menekan progresi siklus sel. Untuk mengetahui apakah peningkatan apoptosis sel Hep G2 setelah pemberian EEP selama 24 jam terkait peningkatan ekspresi p21, maka dilakukan pengamatan peningkatan ekspresi protein) dan masing-masing kelompok perlakuan tersebut dibuat duplicate. Data yang diperoleh berupa persentase sel yang mengekspresikan protein P21 (tampak sebagai warna coklat pada inti sel dan sitoplasma) dari keseluruhan sel pada 5 lapangan pandang dan penilaiannya dilakukan pada 2 slide dari tiap-tiap kelompok perlakuan (Gambar 1).

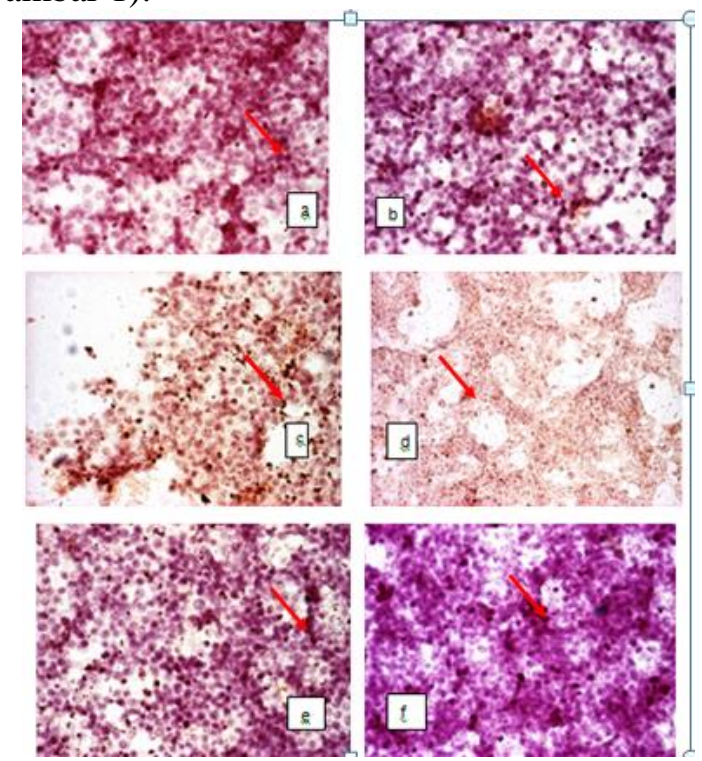

Gambar 1. Hasil pengecatan imunositokimia perbesaran 400 kali untuk ekspresi protein P21 pada sel Hep G2 setelah perlakuan dan inkubasi selama 24 jam pada

kelompok dengan EEP konsentrasi 1/2 IC50 (a), IC50

(b), 2 IC50 (c), Sorafenib (d), Sorafenib dan EEP (e) dan control (f). Sel yang mengekspresikan protein P21ditunjukkan dengan panah warna merah. 


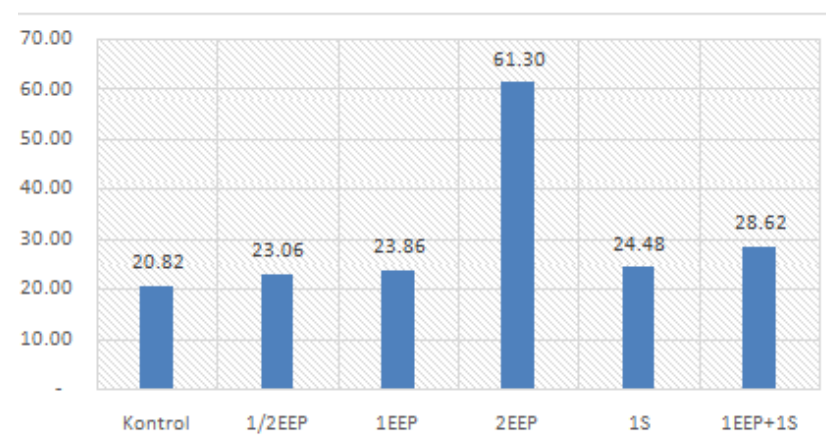

Gambar 2. Grafik hubungan antara konsentrasi bahan uji dengan rata-rata presentase ekspresi P21 pada sel HEp G2 setelah inkubasi 24 jam. Dari grafik di atas, terlihat bahwa pemberian EEP dapat meningkatkan ekspresi Protein p21 dan pemberian S (Sorafenib) maupun gabungan EEP dan Sorafenib akan menghasilkan peningkatan ekspresi Protein p21.

\section{Pengamatan ekspresi protein $\mathrm{Bcl} 2$}

Pengamatan penurunan ekspresi protein Bcl2 digunakan untuk mengetahui apakah peningkatan apoptosis sel Hep G2 setelah pemberian EEP selama 24 jam terkait penurunan ekspresi protein Bcl2. Data yang diperoleh berupa persentase sel yang mengekspresikan protein $\mathrm{Bcl} 2$ (tampak sebagai warna coklat pada inti sel dan sitoplasma) dari keseluruhan sel pada 5 lapangan pandang dan penilaiannya dilakukan pada 2 slide dari tiap-tiap kelompok perlakuan (Gambar 3).

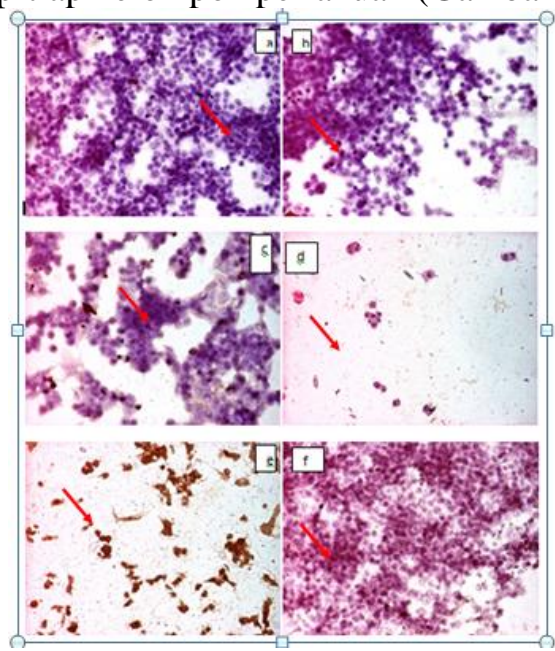

Gambar 3. Hasil pengecatan imunositokimia perbesaran 400 kali untuk ekspresi Bcl2 pada sel HepG2 setelah perlakuan dan inkubasi selama 24 jam pada kelompok dengan EEP konsentrasi 1/2 IC50 (a), $\mathrm{IC}_{50}$ (b), $2 \mathrm{IC}_{50}$ (c), kelompok denganSorafenib (d) kelompok IC50 EEP + Sorafenib (e) dan kelompok kontrol (f). Sel yang mengekspresikan BCl2 ditunjukkan dengan panah warna merah.

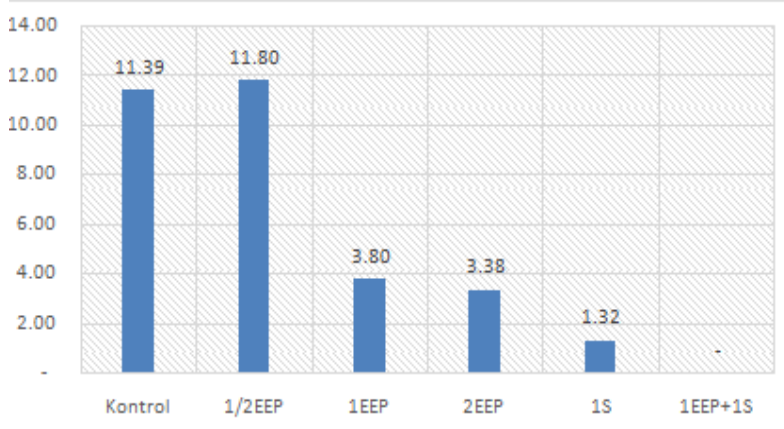

Gambar 4. Grafik hubungan antara konsentrasi bahan uji dengan rata-rata presentase ekspresi Bcl2 pada sel Hep G2 setelah inkubasi 24 jam.

Dari gambar 4 diatas terlihat bahwa pemberian EEP dapat menurunkan ekspresi protein $\mathrm{Bcl} 2$, dan pemberian 1 IC50 EEP + 1IC50 sorafenib menurunkan ekspresi protein $\mathrm{BCl} 2$ lebih baik dariapda pemberian sorafenib sendiri.

4. Pengamatan proliferasi menggunakan doubling time

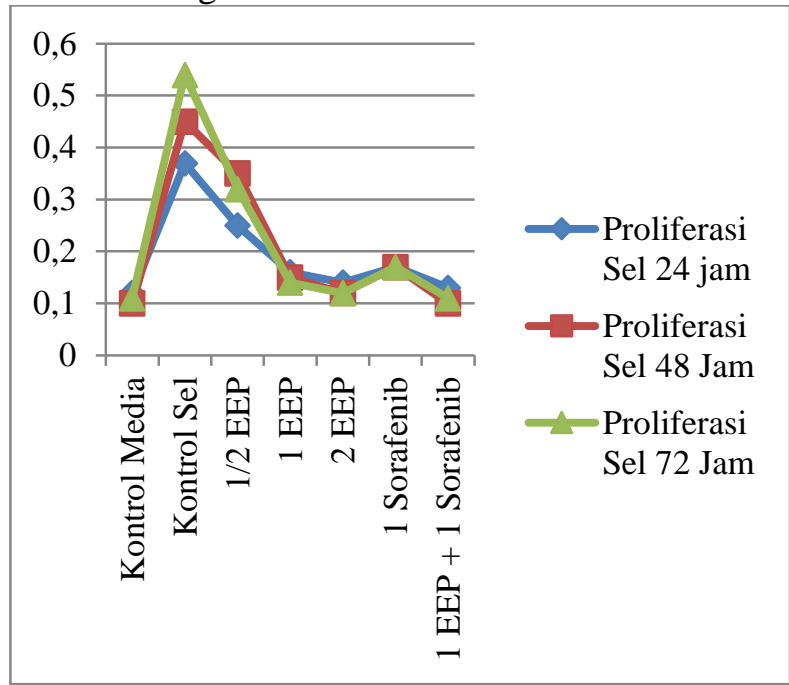

Gambar 5. Proliferasi 24 jam, 48 jam, dan 72 jam. Grafik ini menunjukkan bahwa semua konsentrasi EEP mampu menurunkan proliferasi sel, mulai dari 1/2 IC50, 1IC50, dan 2IC50.

Kekuatan EEP 1IC50 setara dengan Sorafenib IC50 dalam menekan proliferasi 24jam (p>0,05). Kekuatan EEP 0,5IC50 setara dengan Sorafenib IC50 dalam menekan proliferasi 48jam ( $>>0,05)$. Kekuatan EEP 1IC50 lebih baik dari Sorafenib IC50 dalam menekan proliferasi 72jam ( $p>0,05)$. 
5. Pengamatan apoptosis menggunakan flowcytometry

Tabel 2. Rerata Apoptosis Dengan ANOVA

\begin{tabular}{ccccc}
\hline \multirow{2}{*}{ Kelompok } & \multirow{2}{*}{ Rerata \pm SD } & \multicolumn{2}{c}{ ANOVA (Uji F) } \\
Stat-F & Sig \\
\hline \multirow{4}{*}{ Kontrol } & $18,71 \pm 7,21$ & & \\
& 1/2 IC50 EEP & $26,52 \pm 14,72$ & & \\
1 IC50 EEP & $15,75 \pm 8,16$ & & \\
& 2 IC50 EEP & $65,31 \pm 2,27$ & 85,559 & $0,001^{*}$ \\
& 1 Sorafenib & $27,31 \pm 5,31$ & & \\
& 1 IC50 EEP + & $33,42 \pm 14,86$ & & \\
Sorafenib & &
\end{tabular}

Keterangan: * Signifikan pada derajat signifikansi 1 persen.

Perlakuan pemberian 1Sorafenib

menghasilkan nilai rata-rata Apoptosis yang lebih tinggi dibandingkan dengan k-kontrol-sel dan peningkatan Apoptosis akibat Sorafenib itu signifikan pada derajat signifikansi sebesar 5 persen $(\mathrm{p}<0,05)$. Dampak peningkatan Apoptosis akibat perlakuan pemberian 1Sorafenib itu masih jauh dibawah pemberian EEP pada klp-2IC50EEP, klp-1IC50EEP maupun klp-1/2IC50EEP. Hasil itu menunjukkan bahwa pemberian EEP pada ketiga kelompok dosis yang berbeda itu memiliki pengaruh yang cenderung lebih tinggi dibandingkan dengan perlakuan pemberian 1Sorafenib, hal ini dibuktikan dengan adanya perbedaan yang signifikan rata-rata klp-2IC50EEP, klp-1IC50EEP atau klp-1/2IC50EEP masingmasing dengan klp-1Sorafenib dengan tingkat signifikansi sebesar 5 persen $(p<0,05)$.

Penelitian ini diawali dengan uji sitotoksisitas senyawa ekstrak etanol propolis (EEP) pada sel Hep G2 menggunakan metode MTT assay. Uji sitotoksisitas ini dilakukan untuk menetapkan nilai IC50 senyawa EEP yang selanjutnya akan digunakan sebagai dasar penetapan konsentrasi EEP untuk pengamatan ekspresi protein $p 21, B c 2$, bax dan uji apoptosis, proliferasi pada sel Hep G2. Selain itu, uji sitotoksisitas ini juga digunakan untuk menetapkan IC50 Sorafenib pada sel Hep G2 sebagai kontrol positif.

Pada uji sitotoksisitas ini secara umum didapatkan persentase viabilitas sel Hep G2 semakin menurun sebanding dengan peningkatan konsentrasi EEP yang diberikan. Hal ini menunjukkan bahwa pemberian EEP konsentrasi 62,5-250 $\mu \mathrm{g} / \mathrm{mL}$ selama 24 jam mampu menghambat proliferasi sel Hep G2. Hasil ini sejalan dengan beberapa penelitian eksperimen in vitro yang menyatakan bahwa EEP mampu menghambat pertumbuhan berbagai sel tumor dikarenakan mempunyai efek sitotoksik, antiproliferatif dan induksi apoptosis (Kubina et al., 2015).

Aktivitas sitotoksisitas EEP pada sel Hep G2 setelah inkubasi 24 jam dinyatakan dengan nilai IC50 yang diperoleh melalui analisis regresi linear. Pada analisis tersebut diperoleh IC50 EEP pada sel Hep G2 di penelitian ini sebesar 65,19 $\mu \mathrm{g} / \mathrm{mL}$. Studi di Iran pada tahun 2015 menggunakan ekstrak etanol propolis dengan teknik MTT assay dengan dosis IC50 60, 30, and $15(\mu \mathrm{g} / \mathrm{ml})$ in menunjukkan EEP memiliki aktivitas anti proliferasi pada cell line A549 () /sel kanker lambung. Penelitian ini mengindikasikan bahwa komposisi kimia dan farmakokinetik EEP berbedabeda. Hal ini selain dipengaruhi oleh geografis juga dipengaruhi jenis tanaman, asal propolis tersebut diperoleh.

Pada uji sitotoksisitas ini secara umum didapatkan persentase viabilitas sel Hep G2 semakin menurun sebanding dengan peningkatan konsentrasi EEP yang diberikan. Hal ini menunjukkan bahwa pemberian EEP pada penelitian ini mampu menghambat proliferasi dan menurunkan viabilitas sel Hep G2 dengan dosis optimal pada IC50 EEP dan 2 IC50 EEP.

Hasil penelitian membuktikan bahwa EEP dosis 2IC50 EEP mampu menaikkan ekspresi $p 21$ serta menurunkan proliferasi kultur sejalan dengan peningkatan dosis. Hal ini sesuai dengan hasil penelitian ini yang dilakukan Motomura et al. (2008) yang melaporkan bahwa ekstrak etanol propolis konsentrasi $100-1000 \mu \mathrm{g} / \mathrm{mL}$ mampu menghambat pertumbuhan cell line U-937 (sel kanker leukemia) yang sebanding dengan peningkatan konsentrasi yang diberikan. Aktivitas antiproliferatif EEP pada U937 sesuai dengan penelitian dari Motomura et al (2012) digunakan dosis $(100-1000 \mu \mathrm{g} / \mathrm{ml})$. Dosis EEP $300 \mu \mathrm{g} / \mathrm{ml}-$ $500 \mu \mathrm{g} / \mathrm{ml}$, terjadi peningkatan $\mathrm{p} 21$, dan penurunan ekspresi cyclin A, cyclin B, dan CDK.

Hasil penelitian ini juga menunjukkan penurunan kadar bcl2 secara signifikan pada dosis 1 IC50EEP. Dengan penurunan kadar bcl2 diharapkan terjadi peningkatan apoptosis sel kanker. Beberapa penelitian sebelumnya mendukung hasil tersebut. Motomura et al. (2008) juga melaporkan propolis mampu meningkatkan 
apoptosis cell line U-937 (sel kanker leukemia). Sejalan dengan penelitian di atas, Eom et al. (2010) melaporkan bahwa propolis meningkatkan apoptosis melalui pelepasan cytochrome $C$ dari mitokondria ke dalam sitosol pada cell line $H L-60$ (sel kanker leukemia).

Hasil ini sejalan dengan beberapa penelitian eksperimen in vitro yang menyatakan bahwa EEP mampu menghambat pertumbuhan berbagai sel tumor dikarenakan mempunyai efek sitotoksik, antiproliferatif dan peningkatan apoptosis (Kubina et al., 2015).

\section{SIMPULAN}

1. Ekstrak etanol propolis konsentrasi 2IC50 meningkatkan ekspresi p21 pada kultur sel kanker hepatoma (Hep G2).

2. Ekstrak etanol propolis konsentrasi 2IC50 menurunkan ekspresi bcl2 pada kultur sel kanker hepatoma (Hep G2).

3. Ekstrak etanol propolis konsentrasi 1/2 IC50, IC50, dan 2IC50 menurunkan proliferasi sel pada kultur sel kanker hepatoma Hep G2.

4. Ekstrak etanol propolis konsentrasi 2IC50 meningkatkan apoptosis sel pada kultur sel kanker hepatoma Hep G2

\section{DAFTAR PUSTAKA}

Ahmed, F., Perz, J.F., Kwong, S., Jamison, P.M., Friedman, C., Bell, B.P. 2008. National trends and disparities in the incidence of hepatocellular carcinoma, 1998-2003. Prev. Chronic Dis. 5: A74

Ananda, S.K., Tragoolpua, K., Chantawannakul, P., Tragoolpua, Y. 2013. Antioxidant and anticancer cell proliferation of propolis extracts from two extraction methods. Asian Pac J Cancer Prev. 14(11): 6991-6995.

Eom, H.S., Lee, S.J., Yoon, B.S., Yoo, B.S. 2010. Propolis inhibit the proliferation of human leukemia HL60 cells by inducing apoptosis through the mitochondrial pathway. Nat Prod Res. 24:375-386.

Kubina, R., Dzik, A.K., Dziedzic, A., Bielec, B., Wojtczka, R.D., Buldok, R.J., Wysznynska, M., et al. 2015. The ethanol extract of polish propolis exhibits anti-proliferative and/or pro-apoptotic effect on HCT 116 colon cancer and Me45 malignant melanoma cell in vitro conditions. $A d v$ Clin Exp Med. 24(2): 203-212.

Motomura, M., Kwon, K.M., Suh, S.J. 2008. Propolis induces cell cycle arrest and apoptosis in human leukemic U937 cells through Bcl-2/Bax regulation. Environ Toxicol Pharmacol. 26:61-67.

Parkin, D.M., Bray, F., Ferlay, J., Pisani, P. 2005. Global cancer statistics. 2002. Cancer J Clin. 55:74108

Paulino, N., Abreu, S.R.L., Machodo, G., Silveira, E. 2009. Scientific evidences to pharmacological anticancer action of Baccharis dracunculifolia Brazilian propolis. Rev Pesq Inov Farm. 1(1): $15-26$.

Syamsudin, Wiryowidagdo, S., Simanjuntak, P., Heffen, W.L. 2009. Chemical composition of propolis from different region in java and their cytotoxic activity. AJBB.5(4): 180-183.

Watanabe, M.A.E., Amarante, M.K., Conti, B.J., Sforcin, J. M. 2011.Cytotoxic constituents of propolis inducing anticancer effect: a review. JPP. 63: 1378-1386. 